Article

\title{
Effect Of Rapeseed Oil and Mineral Additive in Pig Diet on Physicochemical and Sensory Parameters of Cured Ham
}

\author{
Anna Marietta Salejda 1,*(D), Grażyna Krasnowska ${ }^{1}$, Małgorzata Korzeniowska ${ }^{1}$, \\ Monika Mazur ${ }^{1}$ and Anna Zwyrzykowska-Wodzińska ${ }^{2}$ \\ 1 Faculty of Biotechnology and Food Science, Wrocław University of Environmental and Life Sciences, \\ 37 Chełmońskiego Str., 51-630 Wrocław, Poland; grazyna.krasnowska@upwr.edu.pl (G.K.); \\ malgorzata.korzeniowska@upwr.edu.pl (M.K.); monika.mazur@upwr.edu.pl (M.M.) \\ 2 Faculty of Biology and Animal Science, Wrocław University of Environmental and Life Sciences, \\ 38 c Chełmońskiego Str., 51-630 Wroclaw, Poland; anna.zwyrzykowska@upwr.edu.pl \\ * Correspondence: anna.salejda@upwr.edu.pl
}

Received: 20 August 2020; Accepted: 26 September 2020; Published: 28 September 2020

\begin{abstract}
The aim of the present study was to investigate the effect of modifications of pig-feeding by additions of rapeseed oil and the humus-containing mineral additive Humokarbowit ${ }^{\circledR}$ on selected quality parameters of cured ham. Pig hybrids (Polish Landrace $\times$ Large White Breed) $\times$ Piétrain) were used in the feeding experiments. Humokarbowit ${ }^{\circledR}$ was added up to $4 \%$. Rapeseed oil was added at the dosage of $10 \mathrm{~g} \cdot \mathrm{kg}^{-1}$ of complete diet. The physicochemical, technological and sensory qualities of prepared hams were evaluated. Supplementation of pig diet with rapeseed oil and humus-containing mineral additive did not change the technical parameters of the final product, namely, the yield of the production process and weight losses. Cured hams manufactured meat from pigs fed the supplemented diet were brighter and less yellow than cured hams of pigs fed a normal diet. The applied feed modification contributed also to better storage stability of the meat product color. The control and experimental products did not show significant differences in sensory value. Supplementation of pig diets with rapeseed oil and Humokarbowit ${ }^{\circledR}$ increased content of polyenoic-especially n-3-free-fatty acids, comparing to control group, as well as ratio between n-6 and n-3 FFA. Used additives were effective as feed component in prevention of changes in the fatty acids content of cured hams during storage. In summary, the addition of rapeseed oil and humus-containing preparation to pig diets had a positive effect on raw meat quality and may have a beneficial effects on human health by increased polyenoic fatty acids content.
\end{abstract}

Keywords: feed additives; pork; plant oils; sensory properties

\section{Introduction}

Due to the close connection between the diet and human health, improving the quality of food is a research focus of many scientists. Good nutritional habits have a positive effect on human health, they allow to limit the incidence of most metabolic diseases. Unfortunately, the diet structure of most consumers does not meet the recommendations of dieticians and doctors. An estimated one-third of cancers are associated with diet [1].

Meat and meat products are the basic components of the human diet. Pork meat and its products provide $10-20 \%$ of energy in the diet, and despite the prevailing opinion about its adverse impact on human health (high content of fat and cholesterol, an inappropriate ratio between SFA and UFA) the consumption of this type of meat continues to grow. Therefore, it is advisable to look for possibilities to, e.g., changes in the proportion of fatty acids in tissue [2]. 
Health-related modifications consist of increasing the content of nutritionally desirable ingredients and reducing those that can have a negative impact on human health. The content of nutrients in adipose tissue and meat of the slaughter animals is conditioned by many factors, such as species, breed, age, sex, diet or husbandry conditions. It is possible to produce animal raw materials with a composition appropriate to current nutritional recommendations because the nutritional, health-related, sensory value of raw materials of animal origin can be shaped along the nutritional, pharmacological and/or genetic path. Experiments have demonstrated that pigs quickly and easily react to established breeding criteria. Nutrition is one of the most effective factors affecting the quality of pork meat and fat. Through the appropriately composed fodder (share of protein and metabolic energy, feed additives) and the right way of feeding, one can model the composition of fatty acids, the amount of cholesterol, vitamins and minerals in the raw pork. In recent years, research into the possibility of obtaining high nutritional value of pork has been intensified by modifying the feed, e.g., replacing some of the metabolic energy in fodder with unsaturated fatty acids, necessary for the prevention of cardiovascular diseases [3-5].

Fatty acids as a feed additive fulfill many functions. Among other functions, they increase the productivity of pigs, improve the use of fodder, affect the condition of animals and increase the nutritional value of the feed [6]. The addition of fat to fodder raises its cost, but the expenses incurred are balanced by its lower consumption, larger daily increments and shorter fattening times [2]. Through the targeted supplementation of feed compound with adjuncts rich in polyene fatty acids, it is possible to obtain a meat and fat raw material with the characteristics of functional foods. Polyunsaturated fatty acids-in particular from the n-3 family, ALA, DHA, EPA—can be classified as nutraceuticals, i.e., biologically active substances with demonstrated pro-health effects. Hence, by enriching raw material with them, both meat and fat can be used in the prevention of cardiovascular diseases [7-9].

Vegetable oils are a good source of $n-3$ acids. When used as a component of monogastric animal diets, they increase the content of these acids in pork, with a decrease in saturated acid content. Studies carried out in recent years [10-12] confirm the possibility of modifying pig meat by using in fattening maize grains, rapeseed, linseed, sunflower or soybean oil. The application of the aforementioned feed additives resulted in a significant increase in PUFA content, particularly of the $n-3$ family. The ratio of acids in the n- 6 and n-3 families also changes. Reducing the proportion between these acid has been confirmed to have health-promoting effects. However, the high degree of non-saturation of the raw material reduces the resistance of the tissue to the oxidation process. The content of $\mathrm{C} 18: 3$ (ALA) in muscle lipids should not exceed 3\%, as higher content may cause adverse changes in the taste and flavor profile [13]. PUFA oxidation-in addition to changing the flavor of heat-treated or long-stored meat and fat-can also reduce nutritional value, resulting in losses of vitamins $\mathrm{E}$ and $\mathrm{C}$ and the accumulation of toxic oxysterols. The latest dietary trends regarding the increase in the share of PUFA in the diet also emphasize the desirability of use of antioxidants in the pig diet including vitamins $\mathrm{A}, \mathrm{C}, \mathrm{E}$ and selenium $[9,14-16]$.

The aim of the study was to assess the influence of rapeseed oil and humus-containing mineral additive supplementation on selected quality factors of cured ham from finishing pigs. Rapeseed oil was used as a carrier of polyunsaturated fatty acids. The authors assumed that due to the high content of phenolic compounds, e.g., sinapinic acid and other derivatives with antioxidant properties $[17,18]$ the rapeseed oil will be more oxidative stable than, e.g., linseed oil, when stored during the feeding experiment. In addition, the diet was supplemented with mineral additive prepared from humic brown coal, peat and dolomite and consisted of $30.5 \%$ natural humic acids, $1.95 \%$ bitumen, $1.16 \%$ nitrogen, $5.50 \%$ calcium, $2.95 \%$ magnesium, $1.90 \%$ silicon, $1.00 \%$ sulfur and $0.55 \%$ aluminum. This mineral additive increases the biologic value of feed, showing bactericidal and fungicidal properties, also used in pig nutrition-positive influence on digestive (prevents diarrhea), stimulate immunity of animals, as well as have a positive effect on the quality of animal raw materials [19-21]. The authors expect that this combination of ingredients added to the experimental diet will also have a beneficial impact on the quality of the finished products, i.e., cured ham. 


\section{Materials and Methods}

\subsection{Feeding Experiment}

The study was conducted on raw material collected from pig hybrids (Polish Landrace $\times$ Large White Breed) $\times$ Piétrain). Pigs were divided into two groups of 25 in each — control (ND, normal diet) and experimental group (SD, supplemented diet). In feeding of both groups was used a complete standard isocaloric and isonitrogenous diet (Table 1) applied in two growth phases as previously described by Salejda and Krasnowska [22]. The diet of the experimental group was enriched in Humokarbowit ${ }^{\circledR}$ (humus-containing mineral additive, consisted of humic brown coal, peat and feeding dolomite, $4 \%$ of complete feed, TRONINA Innovative Breeding Company Stanislaw Tronina, Poland) and rapeseed oil (as a source of polyunsaturated fatty acids, $10 \mathrm{~g} \cdot \mathrm{kg}^{-1}$ added in second phase of fattening). The mineral additive was previously mixed with rapeseed oil and then added during mixing of the basic ingredients in the feed mixer. Supplemented diet (SD) with rapeseed oil and mineral additive contained more PUFA of n-3 family, i.e., 3.5\% more than in the normal diet (ND). The mixture used in SD group nutrition also had the most favorable ratio n-6 to n-3 of polyene fatty acids and improved their stability during storage [22].

Table 1. Chemical composition of one kilogram basal diet.

\begin{tabular}{ccc}
\hline & 35-50 kg Body Weight & 50-110 kg Body Weight \\
\hline Energy (kcal) & 3128 & 3105 \\
Crude protein (\%) & 15.9 & 15.0 \\
Crude fiber (\%) & 5.0 & 5.0 \\
Total phosphorus (\%) & 0.63 & 0.63 \\
Dicalcium phosphate (\%) & 0.75 & 0.72 \\
Lysine (\%) & 0.93 & 0.78 \\
Met +Cys (\%) & 0.67 & 0.68 \\
Threonine (\%) & 0.59 & 0.56 \\
Tryptophan (\%) & 0.19 & 0.18 \\
Vitamin A (UI) & 8000 & 5000 \\
Vitamin D (UI) & 1390 & 870 \\
Vitamin E (UI) & 91 & 60 \\
\hline
\end{tabular}

For both feeding groups, the feed meal was offered ad libitum. Pigs were kept in the same environmental conditions and slaughtered with an average live weight of $110 \mathrm{~kg}$ (average meatiness $58 \%$ ). The experimental material (semimembranosus muscles, $\mathrm{sm}$ ) was collected from the right side of ten randomly selected carcasses of each of feeding groups. The samples were delivered $(n=20)$ to the Department of Functional Food Products Development (Wrocław University of Environmental and Life Sciences, Wrocław, Poland) $24 \mathrm{~h}$ after postmortem and stored at $4{ }^{\circ} \mathrm{C}$. The basic chemical and physicochemical parameters of raw material are presented in Table 2

Table 2. Basic chemical and physicochemical parameters of experimental raw material.

\begin{tabular}{cccc}
\hline \multirow{2}{*}{ Parameter } & \multicolumn{3}{c}{ Feeding Groups } \\
\cline { 2 - 4 } & ND & SD & \\
\hline \multirow{2}{*}{ Crude protein $(\%), n=60$} & $22.6 a$ & $22.1 a$ & $\mathrm{X}$ \\
& 0.91 & 0.99 & $\mathrm{sd}$ \\
\hline \multirow{2}{*}{ Crude fat $(\%), n=60$} & $2.67 a$ & $3.25 b$ & $\mathrm{X}$ \\
& 0.12 & 0.16 & $\mathrm{sd}$ \\
\hline
\end{tabular}


Table 2. Cont.

\begin{tabular}{|c|c|c|c|c|}
\hline \multirow{2}{*}{\multicolumn{2}{|c|}{ Parameter }} & \multicolumn{2}{|c|}{ Feeding Groups } & \\
\hline & & ND & SD & \\
\hline \multicolumn{2}{|c|}{ Water $(\%), n=60$} & $\begin{array}{c}73.5 a \\
0.70\end{array}$ & $\begin{array}{c}73.9 a \\
0.62\end{array}$ & $\begin{array}{l}X \\
\text { sd }\end{array}$ \\
\hline \multicolumn{2}{|c|}{$\mathrm{pH}$ value, $n=40$} & $\begin{array}{c}5.51 a \\
0.12\end{array}$ & $\begin{array}{c}5.57 a \\
0.11\end{array}$ & $\begin{array}{c}X \\
\text { sd }\end{array}$ \\
\hline \multicolumn{2}{|c|}{ Drip loss $(\%), n=30$} & $\begin{array}{c}3.53 a \\
0.68\end{array}$ & $\begin{array}{c}3.56 a \\
0.73\end{array}$ & $\begin{array}{c}X \\
\text { sd }\end{array}$ \\
\hline \multirow{3}{*}{ Color, $n=100$} & $\mathrm{~L}$ & $\begin{array}{c}44.3 a \\
1.58\end{array}$ & $\begin{array}{c}43.9 a \\
2.17\end{array}$ & $\begin{array}{l}X \\
\text { sd }\end{array}$ \\
\hline & a & $\begin{array}{c}10.3 a \\
1.61\end{array}$ & $\begin{array}{c}11.04 a \\
1.79\end{array}$ & $\begin{array}{c}X \\
\text { sd }\end{array}$ \\
\hline & $\mathrm{b}$ & $\begin{array}{c}-1.56 a \\
1.10\end{array}$ & $\begin{array}{c}-1.25 \\
a \\
1.92\end{array}$ & $\begin{array}{l}X \\
\text { sd }\end{array}$ \\
\hline
\end{tabular}

ND—raw meat from pigs fed a diet without supplementation; SD—raw meat from pigs fed a diet supplemented with rapeseed oil and mineral additive. $X-$ mean value; sd—-standard deviation; $a, b$-different letters indicate significant differences $(p \leq 0.05)$ between values.

\subsection{Cured Ham Production}

The cured hams were prepared using a basic recipe that was optimized in preliminary studies. For the production, muscle cuts of approximately $200 \mathrm{~g}$ were injected with brine, composed of water $70.74 \%$, curing salt $25 \%$, polyphosphates $2.5 \%$, isoascorbate $0.2 \%$, sucrose $1.3 \%$, monosodium glutamate $0.26 \%$. A $6 \%$ brine injection was used in relation to the sample weight. The cured meat was subjected to heat treatment to achieve a temperature of $72{ }^{\circ} \mathrm{C}$ inside the products. After obtaining this temperature were cooled on ice to ambient temperature. Such prepared samples of cooked hams were subjected to further analyses.

\subsection{Cured Ham Quality Analysis}

An assessment of the technological and sensory quality, as well an analysis of the chemical composition, including free fatty acids profile were carried out.

\subsubsection{Weight Losses and Yield of the Production Process}

Weight losses and yield of production process were estimated in samples after cooking process. Weight losses were expressed as a percentage of initial sample weight. The yield of the cooking process was calculated from the weight ratio of cooked and raw hams.

\subsubsection{Instrumental Color Measurement}

The color of the cooked ham surface was measured by using a reflectance colorimeter Minolta CR-400 (Osaka, Japan) and it was expressed in CIE Lab system parameters: L (lightness, from 0 for black to 100 for white), a (redness, +a: red, $-\mathrm{a}$ : green) and $\mathrm{b}$ (yellowness, $+\mathrm{b}$ : yellow, $-\mathrm{b}$ : blue). The chroma meter was calibrated before each measurement against a standard white tile $(Y=94.2$; $\mathrm{x}=0.313 ; \mathrm{y}=0.320$ ) and set at D65 illuminant and $10^{\circ}$ standard observer. In addition, the assessment of color parameters stability in the products stored for two days in the conditions $\left(4^{\circ} \mathrm{C}, 250 \mathrm{Lx}\right.$, light meter DT-1308, Cem) imitating the illuminated refrigeration counter was performed. 


\subsubsection{Instrumental Texture Analyses-Shear Force}

Shear force $(\mathrm{N})$ measurements were carried out on hams after cooking process. At least 8 cubes of $1 \mathrm{~cm}$ width and high were prepared from each ham. The cubes were sheared perpendicular to the course of the muscle fibers using a Zwick/Roell Z010 testing machine (Zwick Testing Machines, Ltd., Leominster Herefordshire, UK).

\subsubsection{Sensory Evaluation}

A sensory evaluation of cured ham was conducted according to the Polish standard PN-ISO 4121:1998 [23]. Evaluation was performed by six previously trained panelists using a 7-point hedonic rating scale of acceptance [24]. The following parameters of final products were investigated: overall appearance, smell, color, taste, texture and juiciness.

\subsubsection{Fatty Acids Analyses}

Lipids for fatty acids analyses were extracted with standard procedure [25] using methylene chloride and methanol (2:1). Preparation of methyl esters of fatty acids was conducted in accordance with PN-EN ISO 5509:2001 [26]. Chromatographic analysis was performed as previously described by Salejda and Krasnowska [22] using a gas chromatograph coupled with a spectroscopy mass detector (Agilent 6890 N Series, 5973 MS, Agilent Technologies Inc., Santa Clara, CA, USA) and DB-225MS column $(60 \mathrm{~m}, 250 \mu \mathrm{m}, 0.25 \mu \mathrm{m}$, Agilent Technologies Inc., Santa Clara, CA, USA). Samples of $1 \mu \mathrm{l}$ were transferred to the column with the carrier gas (He), split 1:100, column and injector temperatures were set at 160 and $280^{\circ} \mathrm{C}$. Oven (of the spectroscopy mass detector) temperature was set on $140{ }^{\circ} \mathrm{C}$ for $5 \mathrm{~min}$. and after $4{ }^{\circ} \mathrm{C} / \mathrm{min}$ to reach $240^{\circ} \mathrm{C}$. Peak identification was made by comparing the retention times with commercial standards (FAME Mix, Sigma-Aldrich, Inc., St. Louis, MO, USA).

\subsection{Statistical Analysis}

Collected data were statistically evaluated by one-way ANOVA using StatSoft Statistica ${ }^{\circledR}$ Software (2013, StatSoft Polska Sp. z o.o., Kraków, Poland). Duncan test at $p<0.05$ significance level was used to determine the differences between groups. The data are presented as an mean value $(X)$ and accompanied by SD (standard deviation).

\section{Results and Discussion}

According to the assumptions of the experimental work, the technological usefulness of the raw meat obtained from pigs fed with enriched diet was assessed. For this purpose, the production of cured ham made from cuts of semimembranosus muscles of the group of fatteners ND and SD was conducted.

The technological usefulness of the projected raw meat was also determined based on the qualitative evaluation of cured hams (Table 3). The cured ham produced from the meat of pigs fed with the diet supplemented with rapeseed oil and mineral additive (SD group) did not differ significantly in technical parameters, i.e., yield of the production process, weight losses or shear force compared to the meat products of the control group (ND) fed with the diet without oil and mineral additives. Our results were in opposition to those obtained by Stelmasiak, Wyrwisz and Wierzbicka [27]. In their work, the yield of the processing was lowest in the smoked hams manufactured of meat from fatteners whose diet was supplemented with $3 \%$ rapeseed oil and $100 \mathrm{mg}$ vitamin E. At the same time, modification of diet contributed to the lower values of shear force (WBSF) measurement compared to smoked ham produced from raw meat of pigs which diet was not supplemented with $3 \%$ rapeseed oil and $100 \mathrm{mg}$ vitamin E. Differences between the results of our study and those presented by Stelmasiak, Wyrwisz and Wierzbicka [27] may be related with the similar $\mathrm{pH}$ value and protein content of experimental raw materials (Table 2), as the diet modification used did not affect the chemical and physicochemical parameters of raw meat, as it was observed in the aforementioned studies. Protein content and $\mathrm{pH}$ value are the main factors shaping the important characteristics of meat and its preparations 
in production and processing, such as, water capacity, color, tenderness, gelling and emulsification ability [28-30].

Table 3. Weight losses, yield of the process, shear force and color parameters measurement.

\begin{tabular}{|c|c|c|c|c|}
\hline \multirow{2}{*}{\multicolumn{2}{|c|}{ Characteristics }} & \multicolumn{2}{|c|}{ Feeding Groups } & \\
\hline & & ND & SD & \\
\hline \multicolumn{2}{|c|}{ Weight losses $(\%), n=12$} & $\begin{array}{c}10.1 a \\
0.85\end{array}$ & $\begin{array}{c}10.1 a \\
0.8\end{array}$ & $\begin{array}{l}X \\
\text { sd }\end{array}$ \\
\hline \multicolumn{2}{|c|}{$\begin{array}{l}\text { Production yield } \\
\quad(\%), n=12\end{array}$} & $\begin{array}{c}95.8 a \\
0.85\end{array}$ & $\begin{array}{c}95.7 a \\
0.8\end{array}$ & $\begin{array}{l}X \\
\text { sd }\end{array}$ \\
\hline \multicolumn{2}{|c|}{ Shear force $(\mathrm{N}), n=96$} & $\begin{array}{c}29.5 a \\
1.67\end{array}$ & $\begin{array}{c}27.3 a \\
1.66\end{array}$ & $\begin{array}{l}X \\
\text { sd }\end{array}$ \\
\hline $\begin{array}{l}\text { Color parameters } \\
\qquad n=60\end{array}$ & $\begin{array}{l}\mathrm{a} \\
\mathrm{b}\end{array}$ & $\begin{array}{c}70.8 a \\
2.03 \\
10.5 a \\
1.15 \\
3.92 b \\
0.53\end{array}$ & $\begin{array}{c}68.8 b \\
1.81 \\
11.2 b \\
0.93 \\
3.25 a \\
0.58\end{array}$ & $\begin{array}{c}X \\
\text { sd } \\
X \\
\text { sd } \\
X \\
\text { sd }\end{array}$ \\
\hline
\end{tabular}

ND—cured ham produced of raw meat from pigs fed a diet without supplementation; SD—cured ham produced of raw meat from pigs fed a diet supplemented with rapeseed oil and mineral additive. $X-$ mean value; sd —standard deviation; $a, b$-different letters indicate significant differences $(p \leq 0.05)$ between values.

Supplementation of pig diets with rapeseed oil and mineral additive contributed to the lighter color of cured hams. The lighter color observed in present study could be explained by higher fat content in hams produced from SD group. The fat content in raw material was $21.7 \%$ higher in SD group, thus we can assume, that fat content in hams, if measured, would also be higher. Interestingly, this higher fat content did not contribute to greater tenderness of final product either in sensory or instrumental terms. The final products were also less saturated with yellow color (parameter $\left.b^{*}\right)$ compared with hams from pigs that did not receive the experimental additives. These results were in the agreement with those obtained in smoked hams produced of meat from pigs fed a diet supplemented with $3 \%$ rapeseed oil and $100 \mathrm{mg}$ vitamin E [27]. The results of our study demonstrated also better stability of the color parameters of cured hams of SD group than ND group, which were storage in the conditions imitating the illuminated refrigeration counter. This results indicated the possibility of preserving the fresh appearance of products obtained from raw meat of pigs fed with a modified diet. The differences in color assessment, that were mentioned earlier, were not confirmed in the sensory evaluation of cured hams (Figure 1). The evaluators also did not find differences between cured hams of SD and ND group in the following sensory attributes as: general appearance, odor, taste, juiciness, tenderness. Crucially, lack of differences in assessment of tenderness (Figure 1) was confirmed in the instrumental evaluation of cured hams texture (shear force, Table 3).

The diet modification used had a significant effect on the fatty acid profile of cured hams. Hams produced from meat of pig fed diet supplemented with rapeseed oil and mineral preparation (SD group) showed a higher share of unsaturated polyene fatty acids, in particular n-3 fatty acids, than in final product of ND group. In addition, the cured hams of SD group characterized by a more favorable ratio of n-6 to n-3 acids (Table 4). Fatty acids of omega-3 (n-3) and omega-6 (n-6) group have important functions in many biochemical transformations and regulate many physiological activities of the human body. Not all fatty acids can be synthesized by the human body and must be supplied with food. Dietary supplementation of enriched with fatty acids meat can be an alternative to increase the daily intake of this crucial components [31]. The positive effect of addition to pig diet oils rich in polyunsaturated fatty acids (PUFA) on raw meat was also presented in previous studies, e.g., Leikus et al. [32] and Sobol et al. [33]. However, the higher amount of PUFA can affect meat quality owing to peroxidative changes. Thus, it is recommended to apply to diet also with oil components natural antioxidants, 
which have greater potential to prevent oxidative damage and at the same time to increase shelf-life of meat products [34,35]. Our studies have shown that using feed component (rapeseed oil) rich in polyunsaturated fatty acids lead to production of cured ham beneficial for consumer health due to the ratio of saturated and unsaturated fatty acids. At the same time, the changes of fatty acids content in meat products during storage, were observed only in ND group, which may be related to the additives used in experimental diet. It can be assumed that addition of rapeseed oil, which characterized by high phenolic content (sinapinic acid and other derivatives with antioxidant properties), increases the biologic value of feed and also have a positive influence on raw meat quality $[17,18]$ and efficiently limited the oxidative changes in fatty acid profile of cured hams. This effect may be accelerated by the addition of mineral additive which also exhibited antioxidant activity in radical scavenging and electrochemical assays [36].

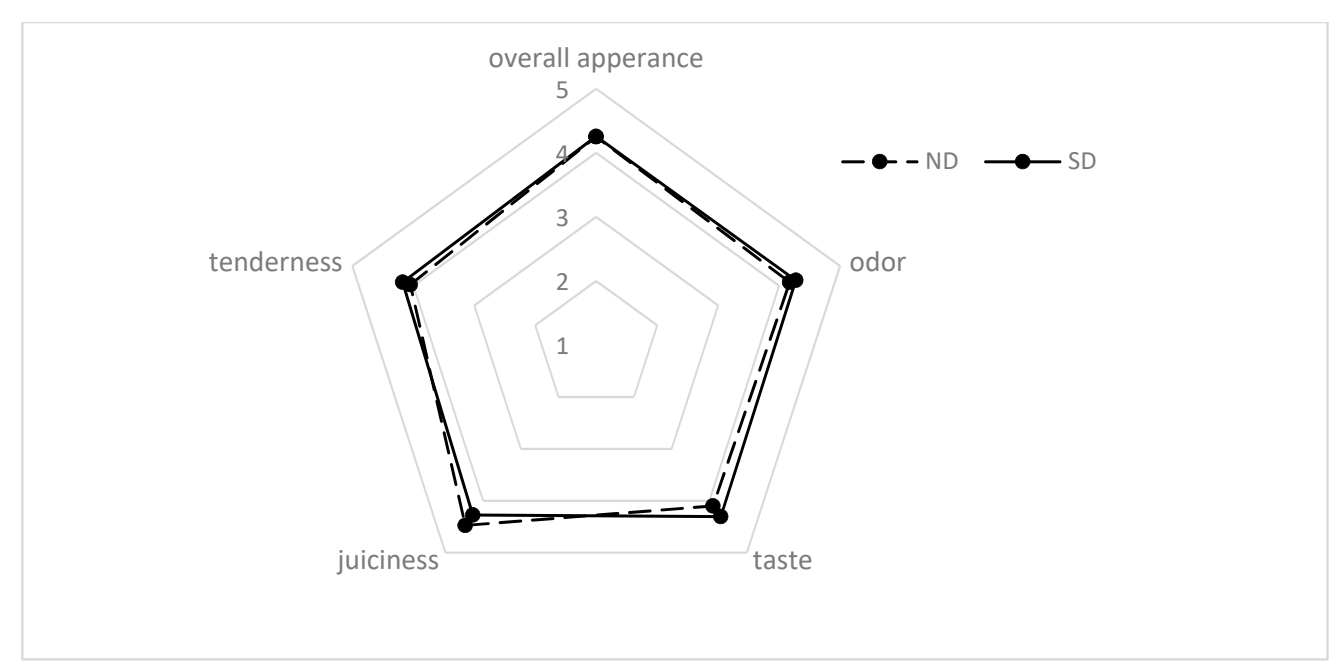

Figure 1. Sensory profile of cured hams. ND—cured ham produced of raw meat from pigs fed a diet without supplementation, SD—cured ham produced of raw meat from pigs fed a diet supplemented with rapeseed oil and mineral additive.

Table 4. Fatty acids profile of cured ham $(n=24)$. ND—cured ham produced of raw meat from pigs fed a diet without supplementation; SD—cured ham produced of raw meat from pigs fed a diet supplemented with rapeseed oil and mineral additive. $a, b$-different letters indicate significant differences $(p \leq 0.05)$ between values.

\begin{tabular}{cccc}
\hline \multirow{2}{*}{$\begin{array}{c}\text { Fatty Acid Groups } \\
(\%)\end{array}$} & \multicolumn{3}{c}{ Feeding Groups } \\
\cline { 2 - 4 } & & ND & SD \\
\hline \multirow{2}{*}{ Saturated } & $\mathrm{X}$ & $37.7 b$ & $35.3 a$ \\
& $\mathrm{sd}$ & 0.36 & 0.7 \\
\hline \multirow{2}{*}{ Monoenoic fatty acids } & $\mathrm{X}$ & $46.7 a$ & $48.2 b$ \\
& $\mathrm{sd}$ & 0.6 & 0.6 \\
\hline \multirow{2}{*}{ Polyenoic fatty acids } & $\mathrm{X}$ & $15.6 a$ & $16.4 b$ \\
& $\mathrm{sd}$ & 0.4 & 0.1 \\
\hline \multirow{2}{*}{ N-3 polyenoic fatty acids } & $\mathrm{X}$ & $0.65 a$ & $1.71 b$ \\
& $\mathrm{sd}$ & 0.06 & 0.1 \\
\hline \multirow{2}{*}{$\mathrm{N}-6$ polyenoic fatty acids } & $\mathrm{X}$ & $14.9 b$ & $14.7 a$ \\
& $\mathrm{sd}$ & 0.65 & 0.6 \\
\hline Ratio n-6/n-3 & $\mathrm{X}$ & $23.0 / 1 b$ & $8.6 / 1 a$ \\
\hline
\end{tabular}

ND—cured ham produced of raw meat from pigs fed a diet without supplementation; SD—cured ham produced of raw meat from pigs fed a diet supplemented with rapeseed oil and mineral additive. $X$-mean value; sd—standard deviation; $a, b$-different letters indicate significant differences $(p \leq 0.05)$ between values. 


\section{Conclusions}

Supplementation of pig diets with rapeseed oil and mineral additive did not affect the technical parameters of cured hams such as yield of technological process and weight losses. There were also no significant differences in values of instrumental texture measurement expressed by shear force. Furthermore, addition of oil and humus-containing mineral additive did not result in deterioration of sensory acceptability, what is important from the consumer point of view. Rapeseed oil and mineral additive were effective as feed component in prevention of changes in the fatty acids content of cured hams. These findings suggest that used additives should be considered as a natural feed components. However, further studies, e.g., a TBARS assay, should be conducted to confirm the oxidation stability of final products.

Author Contributions: Conceptualization, A.M.S.; Formal analysis, A.M.S.; Investigation, A.M.S.; Methodology, A.M.S.; Resources, G.K.; Supervision, G.K.; Validation, M.K.; Visualization, A.Z.-W.; Writing-original draft, A.M.S. and M.M.; Writing-review \& editing, M.K. All authors have read and agreed to the published version of the manuscript.

Funding: The manuscript was co-funded by the support project from the subsidy increased for the period 2020-2025 in the amount of 2\% of the subsidy referred to Art. 387 (3) of the Law of 20 July 2018 on Higher Education and Science, obtained in 2019.

Acknowledgments: We would like to appreciate Bronislaw Koncewicz and Wojciech Tronina for their kind cooperation.

Conflicts of Interest: The authors declare no conflict of interest.

\section{References}

1. Giovannucci, E. A framework to understand diet, physical activity, body weight, and cancer risk. Cancer Causes Control 2018, 29, 1-6. [CrossRef] [PubMed]

2. Mielczarek, A.; Osek, M.; Olkowski, B.; Klocek, B.; Lipnicka, A. The comparison of fattening results, slaughter value and meat quality of pig crossbreeds pulawska $x$ polish large white and polish landrace $x$ polish large white. Acta Sci. Pol. Zootech. 2012, 11, 31-40.

3. Rosenvold, K.; Andersen, H.J. Factors of significance for pork quality. A review. Meat Sci. 2003, 64, $219-237$. [CrossRef]

4. Andersen, H.J.; Oksbjerg, N.; Young, J.F.; Therkildsen, M. Feeding and meat quality-a future approach. Meat Sci. 2005, 70, 543-554. [CrossRef] [PubMed]

5. Calvo, L.; Segura, J.; Toldrá, F.; Flores, M.; Rodríguez, A.I.; López-Bote, C.J.; Rey, A.I. Meat quality, free fatty acid concentration, and oxidative stability of pork from animals fed diets containing different sources of selenium. Food Sci. Technol. Int. 2017, 23, 716-728. [CrossRef]

6. Upadhaya, S.D.; Li, T.S.; Kim, I.H. Effects of protected omega-3 fatty acid derived from linseed oil and vitamin $\mathrm{E}$ on growth performance, apparent digestibility, blood characteristics and meat quality of finishing pigs. Anim. Prod. Sci. 2017, 57, 1085-1090. [CrossRef]

7. Pennington, J.A.T. Food composition databases for bioactive components. J. Food Comp. Anal. 2002, 15, 419-434. [CrossRef]

8. Apple, J.K. Nutritional Effects on Pork Quality in Swine Production. Pork Information Gateway. 2015. Available online: https://porkgateway.org/resource/nutritional-effects-on-pork-quality-in-swine-production2/ (accessed on 18 August 2020).

9. Jasińska, K.; Kurek, M.A. The effect of oil plants supplementation in pig diet on quality and nutritive value of pork meat. Anim. Sci. Pap. Rep. 2017, 35, 137-146.

10. Nuernberg, K.; Fischer, K.; Nuernberg, G.; Kuechenmeister, U.; Klosowska, D.; Eliminowska-Wenda, G.; Fiedler, I.; Ender, K. Effect of dietary olive and linseed oil lipid composition, meat quality, sensory characteristics and muscle structure in pigs. Meat Sci. 2005, 70, 63-74. [CrossRef]

11. Realini, C.E.; Duran-Montgé, P.; Lizardo, R.G.; Gispert, M.; Oliver, M.A.; Estevegarcia, E. Effect of source of dietary on pig performance, carcass characteristics and carcass fat content, distribution and fatty acid composition. Meat Sci. 2010, 85, 606-612. [CrossRef] 
12. Ranucci, D.; Beghelli, D.; Trabalza-Marinucci, T.; Branciari, R.; Forte, C.; Olivieri, O.; Badillo Pazmay, G.V.; Cavallucci, C.; Acuti, G. Dietary effects of a mix derived from oregano (Origanum vulgare L.) essential oil and sweet chestnut (Castanea sativa Mill.) wood extract on pig performance, oxidative status and pork quality traits. Meat Sci. 2015, 100, 319-326. [CrossRef] [PubMed]

13. Wood, J.D.; Richardson, R.I.; Nute, G.R.; Fisher, A.V.; Campo, M.M.; Kasapidou, E.; Sheard, P.R.; Enser, M. Effects of fatty acids on meat quality: A review. Meat Sci. 2003, 66, 21-32. [CrossRef]

14. Corino, C.; Magni, S.; Pagliarini, E.; Rossi, R.; Pastorelli, G.; Chiesa, L.M. Effects of dietary fats on meat quality and sensory characteristics of heavy pig lions. Meat Sci. 2002, 60,1-8. [CrossRef]

15. Haak, L.; Raes, K.; Smet, K.; Claeys, E.; Paelinck, H.; De Smet, S. Effect of dietary antioxidant and fatty acid supply on the oxidative stability of fresh and cooked meat. Meat Sci. 2006, 74, 476-486. [CrossRef]

16. Estevez, M. Oxidative damage to poultry: From farm to fork. Poult. Sci. 2015, 94, 1368-1378. [CrossRef]

17. Siger, A.; Gawrysiak-Witulska, M.; Bartkowiak-Broda, I. Antioxidant (tocopherol and canolol) content in rapeseed oil obtained from roasted yellow-seeded Brassica napus. J. Am. Oil Chem. Soc. 2017, 94, 37-46. [CrossRef]

18. Szydłowska-Czerniak, A.; Rabiej, D. Octyl sinapate as a new antioxidant to improve oxidative stability and antioxidant activity of rapeseed oil during accelerated storage. Eur. Food Res. Technol. 2018, 244, 1397-1406. [CrossRef]

19. Islam, K.M.S.; Schuhmacher, A.; Gropp, J.M. Humic acid substances in animal agriculture. PJN 2005, 4, 126-134.

20. Grzelak, A.; Bubel, F.; Tronina, P.; Tronina, S. Method of Manufacturing of Humic-Herbal-Mineral Preparations. Patent No. PL215300-B1, 25 September 2008.

21. Humokarbowit Description. Available online: http://www.tronina.pl/oferta/humokarbowit/ (accessed on 16 September 2020).

22. Salejda, A.M.; Krasnowska, G. Effect of dietary rapeseed oil and humus-containing mineral preparation on cholesterol and cholesterol oxidation products content in pork. Eur. Food Res. Technol. 2016, 242, 1441-1446. [CrossRef]

23. PN-ISO 4121:1998 Sensory Analysis-Methodology-Evaluation of Food Products by Method Using Scales; Polish Committee for Standardization: Warszawa, Poland, 1998.

24. Lewless, H.T.; Hildegarde, H. Sensory Evaluation of Food. Principles and Practices, 2nd ed.; Springer: New York, NY, USA, 2010.

25. Folch, J.; Lees, M.; Stanley, G. A simple method for the isolation and purification of total lipids from animal tissues. J. Biol. Chem. 1957, 226, 497-509.

26. PN-EN ISO 5509:2001 Animal and Vegetable Fats and Oils-Preparation of Methyl Esters of Fatty Acids; Polish National Standard Based on ISO 5509:2000; Polish Committee for Standardization: Warszawa, Poland, 2001.

27. Stelmasiak, A.; Wyrwisz, J.; Wierzbicka, A. Pig diet with bioactive compounds influences quality of meat and smoked ham. S. Afr. J. Anim. Sci. 2018, 48, 1032-1041. [CrossRef]

28. Huff-Lonergan, E. Chemistry and biochemistry of meat. In Handbook of Meat Processing; Toldra, F., Ed.; Wiley-Blackwell: Hoboken, NJ, USA, 2010; pp. 5-25.

29. Chiavaro, E.; Rinaldi, M.; Vittadini, E.; Barbanti, D. Cooking of pork Longissimus dorsi at different temperature and relative humidity values: Effects on selected physico-chemical properties. J. Food Eng. 2009, 93, 158-165. [CrossRef]

30. Hayes, J.E.; Stepanyan, V.; Allen, P.; O'Grady, M.N.; Kerry, J.P. Evaluation of the effects of selected plant-derived nutraceuticals on the quality and shelf-life stability of raw and cooked pork sausages. LWT Food Sci. Technol. 2011, 44, 164-172. [CrossRef]

31. Alagawany, M.; Elnesr, S.S.; Farag, M.R.; Abd El-Hack, M.E.; Khafaga, A.F.; Taha, A.E.; Tiwari, R.; Yatoo, M.I.; Bhatt, P.; Khurana, S.K.; et al. Omega-3 and omega-6 fatty acids in poultry nutrition: Effect on production performance and health. Animals 2019, 9, 573. [CrossRef] [PubMed]

32. Leikus, R.; Juskiene, V.; Juska, R.; Juodka, R.; Stankeviciene, D.; Nainiene, R.; Siukscius, A. Effect of linseed oil sediment in the diet of pigs on the growth performance and fatty acid profile of meat. R. Bras. Zootec. 2018, 47, e20170104. [CrossRef]

33. Sobol, M.; Raj, S.; Skiba, G. Effect of fat content in primal cuts of pigs fed diet enriched in n-3 polyunsaturated fatty acids on health-promoting properties of pork. J. Anim. Feed Sci. 2016, 25, 20-28. [CrossRef] 
34. Schiavone, A.; Marzoni, M.; Castillo, A.; Nery, J.; Romboli, I. Dietary lipid sources and vitamin E affect fatty acid composition or lipid stability of breast meat from Muscovy duck. Can. J. Anim. Sci. 2010, 90, 371-378. [CrossRef]

35. Kishawy, A.T.; Amer, S.A.; Abd El-Hack, M.E.; Saadeldin, I.M.; Swelum, A.A. The impact of dietary linseed oil and pomegranate peel extract on broiler growth, carcass traits, serum lipid profile, and meat fatty acid, phenol, and flavonoid contents. Asian Australas. J. Anim. Sci. 2019, 32, 1161-1171. [CrossRef]

36. Zykova, M.V.; Schepetkin, I.A.; Belousov, M.V.; Krivoshchekov, S.V.; Logvinova, L.A.; Bratishko, K.A.; Yusubov, M.S.; Romanenko, S.V.; Quinn, M.T. Physicochemical characterization and antioxidant activity of humic acids isolated from peat of various origins. Molecules 2018, 23, 753. [CrossRef]

(C) 2020 by the authors. Licensee MDPI, Basel, Switzerland. This article is an open access article distributed under the terms and conditions of the Creative Commons Attribution (CC BY) license (http://creativecommons.org/licenses/by/4.0/). 